\title{
The Impact of Sustainability on the Financial Performance of Jordanian Islamic Banks
}

\author{
Ali Abdelfattah Hamdan Zyadat ${ }^{1}$ \\ ${ }^{1}$ School of Business, Al-Balqa' Applied University, Salt, Jordan \\ Correspondence: Ali Abdelfattah Hamdan Zyadat, Department of Economics, Faculity of Business, Al-Balqa' \\ Applied University, Al Salt, 19117, Jordan. Tel: 962-772-036-288. E-mail: Alzyadat_1960@yahoo.com
}

Received: July 9, 2016

doi:10.5539/ijef.v9n1p55
Accepted: July 29, 2016

Online Published: December 14, 2016

URL: http://dx.doi.org/10.5539/ijef.v9n1p55

\begin{abstract}
The study looked into the effect of the three dimensions of sustainability (economic dimension, environmental dimension, and social dimension) on the financial performance of Jordanian Islamic banks represented by (return on assets, return on equity, and earnings per share) during the period (2008-2014). The study sample contained two main Islamic banks in Jordan, namely: Jordan Islamic Bank and Arab Islamic Bank. Required data was collected from the annual reports, financial statements, sustainability reports, and social responsibility reports of the Jordanian Islamic banks from (2008-2014). Items for the dimensions of sustainability were determined, and their level of exercise was measured, by analyzing the content of these reports (content analysis), as well as the financial indicators of financial performance, which have been extracted from the financial statements of the surveyed banks. The study results have shown the presence of a statistically significant effect of the dimensions of sustainability on the financial performance measured by ROA and EPS in the Jordanian Islamic banks. However, there was no statistically significant effect of the dimensions of sustainability on the financial performance as measured by ROE in those banks. Finally, the study has encouraged Islamic banks to adopt a rational and prudent investment and financial policies, make proper operational decisions to generate revenue, maximize profits, and achieve shareholder objectives, issue sustainability reports to discover if goals and activities are compatible to the goals and interests of society and the environment, and increase their interest in sustainability.
\end{abstract}

Keywords: sustainability, environmental dimension, economic dimension, social dimension, financial performance, Earnings per Share (EPS), Rate of Return on Equity (ROE), Return on Assets (ROA), Islamic banks

\section{Introduction}

Sustainability is a major global concern. It is highly associated with the elements and ingredients ensuring the survival of life on Earth. This modern concept is also integrated with the overall aspects of human life (social, environmental, and economic), which were later considered the three pillars of sustainability (United Nations General Assembly, 2005). The first beginnings of "sustainability" as an official term can be dated back to the eighties of the last century, where it addressed the survival of humanity on the planet - The most common sustainability concepts (IUCN/UNEP/WWF, 1991). In 1987, Brundtland committee asked institutions and companies to include plans that reveal its environmental and social activity within its overall strategy by setting up a special management for sustainability and approve this new management to the regulatory framework (Schallegger \& Wagner, 2006).

Nowadays, this topic has become one of the mainstays by which institutions ensure their survival and continuity. The success of organization is now determined by social and environmental performance, as well as achieving financial objectives. The main gateway leading to the achievement of sustainability is taking into account the effects organizations' operating activities leave behind and their impact on the environment and society. Any organization must include this perspective in its fundamental objectives along with its ongoing pursuit to maximize revenues and profits (Rankin, Stanton, McGowan, Ferlauto, \& Tilling, 2012).

The achievement of fiscal targets, represented in earning money and profits, is the first objective of all banks. Therefore, there is a urgent need to focus more on the financial performance of the banks, for it represents a gateway toward achieving fiscal targets and the source of information on which organizations use for planning, 
control, and decision-making processes. It's worth mentioning that any defect or deficiency can affect the financial performance of banks and put the survival and continuity of the bank at risk. Therefore, attention should be drawn to the impact of the dimensions of sustainability on the financial performance in Islamic banks.

\subsection{Problem of the Study}

Financial performance is crucial for banks to achieve their goals of survival, development, and continuity in light of the internal or external challenges they face on daily basis. It represents the true translation of the plans and projects the organization adopts to invest their property, e.g. resources, capabilities, and equipment, in order to serve their purpose and achieve their interests.

Banks generally seek to achieve ample returns from its financial and investment activities and operations. Therefore, sustainability should be part of all activities and processes associated with environmental, economic, and social areas. Consequently, this study has been developed to look at the impact of sustainability on the financial performance of Jordanian Islamic banks.

The problem of the study is an attempt to answer the following question:

Is there an effect of the three dimensions of sustainability (economic dimension, environmental dimension, and social dimension) on the financial performance of Jordanian Islamic banks represented by (return on assets, return on equity, and earnings per share)?

\subsection{Importance of the Study}

The importance of the study stems from many factors. It explores the economic, developmental role of the banking sector in Jordan as one of the most important financial sectors, and deals with the field of Islamic banking industry, which is characterized by its commitment to the provisions and principles of the Islamic Sharia. This study is quite significant, because it looks into the impact of sustainability on the financial performance of the Jordanian Islamic banks; an effect which contributes to the enrichment of Arab and Jordanian libraries in this regard.

\subsection{Objectives of the Study}

The study aims to provide a clear and comprehensive vision for the managers and owners of Jordanian Islamic banks on the effect of the dimensions of sustainability on the financial performance of those banks. The accomplishment of this objective will contribute to the improvement of financial performance by predicting the financial implications of all these dimensions, and thus assist in the development of strategies and decisions that ensure sustainability and continuity.

\subsection{Hypotheses}

The hypotheses of the study could be formulated by means of the study's questions as follows:

The first main hypothesis H0-1: There is no statistically significant effect for the dimensions of sustainability on the financial performance as measured by return on assets ROA in Jordanian Islamic banks.

The second main hypothesis H0-2: There is no statistically significant effect for the dimensions of sustainability on the financial performance as measured by return on equity ROE in Jordanian Islamic banks.

The third main hypothesis H0-3: There is no statistically significant effect for the dimensions of sustainability on the financial performance as measured by return per stock EPS in the Jordanian Islamic banks.

\subsection{Study Model}

The following figure shows the proposed study model:

\begin{tabular}{|c|c|}
\hline Dimensions of Sustainability & Financial Performance \\
\hline Economic dimension & Return on assets \\
\hline Environmental dimension & Return on equity \\
\hline Social dimension & Return per stock \\
\hline
\end{tabular}

Figure 1. Study model

\section{Theoretical Framework and Previous Studies}

\subsection{Sustainability}

Upon the creation of the concept of sustainable development by Brundtland committee in 1987, the committee 
formulated the primary aim of this concept, which is meet the needs and requirements of the present society without affecting the energy of the next community when it comes to securing its needs and requirements. Sustainability is defined as "An institution's ability to adopt additional activities that push it towards facing events and changes relating to economic, social, and ecological environment, and the risk management resulting therefrom. This ability affects the reputation and presence of the institution, as well as liability and opportunities management, which promotes creativity and innovation and increases its ability to cope with the course of the internal and external environment" (Bansal \& Ivey, 2013). Many consider sustainable development to be recognition of the role of society in the protection of its resources and ensuring the continuity of life on Earth (Albu et al., 2011).

Many international institutions have produced several definitions of "sustainable development". Organization for Economic Cooperation and Development (OECD) has defined it as "an economic development based on achieving net return and profits on the condition of preserving environmental and social systems by finding a way of flexible interaction (OECD, 2002). And the International Federation of Accountants (IFAC) defined it as "An institution's ability to create continuous value as an economic unit" (IFAC, 2006).

Researchers and specialists in the field of sustainability have agreed that sustainable development is based on three dimensions that are considered the essential pillars of sustainability (United Nations General Assembly, 2005). These dimensions are:

1. Environmental dimension: This dimension provides ecosystems protection (land, air, and water), preservation of energy resources, access to renewable sources of resources, and increase in the ability to cope with the events and environmental changes (Smouts, 2005, p. 5).

2. Economic dimension: One of the first dimensions upon which development was created. It focuses on achieving sustainability of the economic construction through efficient use of the capital and resources, provision of basic needs and requirements of the individual, improvement of standard of living by maximizing returns from products and services, and achievement of economic justice (Godard, 2010, p. 69).

3. Social dimension: This dimension achieves social justice and equality in the distribution of natural and economic resources. It also promotes social interaction and participation in local communities, develops cultural diversity, and cares for human rights and its respect (Smouts, 2005, p. 5).

\subsection{Financial Performance}

Financial performance is a concept describing the financial aspects of banks, which are the major reason for the establishment and inception of these establishments. It is used as a measure of the bank's financial position during a specific period of time (Dufera, 2010, p. 16). Financial performance is of great importance to banks, since it opens the way for the bank's management to determine the level of the bank's overall performance, stand on the strengths and weaknesses of the performance, seize investment opportunities, secure the needs and accomplish the goals of all individuals who have ties with the bank, enhance the bank's competitive position among other banks, achieve competitive advantage, provide the ability to reduce pressure on stakeholder's equities, and highlight the importance of the bank's financial performance in the measurement of its ability to cope with external threats and adapt to events and developments, since financial performance is considered a good indicator of a bank's ability to deal with external events in its environment.(Dufera, 2010, p. 5).

Financial performance evaluation is defined as: "Pursue and review of achieved objectives based on specific criteria consistent with the plans and strategic objectives of the bank. These actions monitor performance and compare it with the planned objectives and determine the performance of individuals in various administrative levels in order to reach the strategic objectives of the bank" (Poster \& Streib, 2005, p. 46).

Performance measurement is considered a method of assessment. This means that the process has tools used to achieve the measurement process, which are called "Performance evaluation measures (indicators)". The evaluation process is done by comparing the actual performance of the bank to the planned performance within a particular range, and any deviation from the scope of this term reflects a defect in the performance of the bank (Egos, 2005, p. 16).

The management of banking institutions depends on financial measurements to assess the financial performance. These measurements represent the other side of the results of operational performance measurement for banks, which aims to measure the extent to which the bank's strategy achieves the objectives. This side reflects the financial shape of the output of the operational performance measurement process (Sinkey, 2008, 0.153). These measurements are shown in the form of financial ratios derived from the profitability ratios, debt ratios, liquidity ratios, and financial management performance ratios (efficiency), which appear in various financial statements 
(Babaloa \& Abiola, 2013, p. 132). The use of many of these standards has been popularized in order to measure the financial performance of banks. These standards include:

\section{1). Earnings per Share (EPS)}

This measurement is also called "earnings per share". It aims to measure profitability of banks and financial institutions and support the decisions of investors (Reid \& Myddelton, 2005, p. 46). Return on equity refers to earnings per share. It represents the earnings per dinar in a certain period of time, and is expressed mathematically as follows (Weygandt et al., 2010, p. 43):

$\mathrm{ROE}=$ Net profit (after deducting taxes) / the number of current shares $\mathrm{x} 100 \%$

\section{2). Rate of Return on Equity (ROE)}

The rate of return on equity is designed to measure the profit shareholders earned from the employment of their money in the bank's capital. It is expressed as the result of dividing the net profit (after deducting taxes) on shareholders' equity, which includes paid-in capital, premiums, reserves, and retained earnings, and is expressed mathematically as follows (Gibson, 2013, p. 40):

Rate of return on equity $=$ Net profit (after deducting taxes) $/$ Shareholders' equity $\times 100 \%$

\section{3). Return on Assets (ROA)}

The rate of return on assets is designed to measure the efficiency of the bank's management when it comes to the use of its assets to generate profits. It is expressed as the result of dividing the bank's net profit after deducting tax on the total assets of the bank, and is expressed mathematically as follows (Gibson, 2013, p. 40):

ROA $=$ Net profit (after deducting taxes) / Total assets $\mathrm{x} 100 \%$

\subsection{Previous Studies}

Many studies have examined the subject of sustainability from several aspects and addressed its impact on various areas where organizations function within the business environment.

Regarding sustainability reports, Guidry and Patten study, (2010) examined the responses of the financial market on the sustainability report launched by US companies in 2009, which was sent to the shareholders of these companies and adopted a methodology to predict the return per share for the company. The study found that companies that produced a high quality sustainability report received more positive market responses than companies that produced low quality reports.

Thomas and Vos study (2012) attempted to analyze the sustainability report for five of the major international companies in the logistics industry in 2011. This endeavor tried to discover what these companies offer towards an environmental sustainability management. On this basis, possible motives were discussed upon the disclosure of the sustainability report. The study discovered that the sustainability report of the analyzed companies tend to be transparent to some extent, and that most of the information published was related to the sustainability strategy. The report also focused on ways to reduce dioxide carbon emissions by reporting emission factors.

Regarding the dimensions of sustainability, Inoue and Lee study (2011) classified social responsibility activities by its voluntary nature. It also studied the effect of these activities on the financial performance of companies in Macedonia. The study covered four sectors of tourism, which are hotels, airlines, restaurants, and tourist clubs by studying (5) dimensions, namely: employee relations, product quality, community relations, environmental issues, issues of diversity. The study results revealed that every one of the five activity proposed by the researchers have a different effect on the company's profitability and sustainability.

Gonzalez and Adams study, (2012) addressed the social and environmental accounting issues related to organizations that deal with the management and reporting of sustainability, and reviewed the most important contributions to this area. The study revealed that the extensive literature in the field of sustainable reporting and accounting have been neglected to a large extent due to fears of a further increase in the number of participants in the social accounting business agenda. The study concluded that there should be larger studies in the accounting systems on sustainability. It also proposed a range of solutions to the accounting reports for sustainability and further research related to sustainability, accounting systems, and management. Such research can be used to yield the benefits of methodological and theoretical ideas contained in other disciplines.

Macarulla and Talalweh study (2012) focused on finding out the level of disclosure of social responsibility in the financial reports of the Saudi companies. It also compared between the level of disclosure of these companies and their properties by studying the annual reports of a sample of 132 companies listed on the Riyadh Stock Exchange for the year 2008 depending on content analysis. The study used the index to measure the qualitative 
and quantitative disclosure of the social responsibility activities, human, social and environmental resources. The study found that the disclosure of social responsibility in the Saudi companies is substantially low. The results of the study showed a relationship between the size of the company, the economic sector, and profitability at the level of disclosure of social responsibility activities.

Zvedov study (2012) drew a link between performance and sustainability. The study aimed to provide a comprehensive basis for decision-making and performance monitoring in light of the opportunities for corporate sustainability, the threats they face, and how to deal with sustainability accounting. The study's sample was composed of 16 companies operating in the UK and Germany. Information was collected through personal interviews with 58 directors of these companies, who represent the providers and users of sustainability information. The obtained data was analyzed on the basis of (a) If the issue received recognition, or (b) has been recognized and not addressed, or (c) has been recognized and addressed, or (d) solutions have been developed and successfully applied. The study found that sustainability accounting is critical in addressing key issues the companies face. The study identified future challenges for late adopters and laid the basis for the directors to consider the adoption of good accounting practices in sustainability.

Studying previous studies makes it possible to notice the scarcity of studies on the impact of sustainability on financial performance. It appears that most studies focus on companies in general. This fact introduces a special characteristic to this study, since it looks into the most important sectors on which the country's economy rely and addresses Islamic banks specifically

\section{Study Metholodegy and Procedures}

This descriptive and analytical study aims to recognize the presence of a significant effect of the level of practice of sustainability dimensions on the financial performance indicators in Jordanian Islamic banks.

\subsection{Study Sample and Population}

The study population consisted of all Jordanian Islamic banks, which are (3) banks: Jordan Islamic Bank, Islamic Arab Bank, and Jordan Dubai Islamic Bank. Annual reports of the aforementioned banks have been studied from (2008-2014), as well as the changes in the indicators of financial performance. Therefore, Jordan Dubai Islamic Bank was excluded for being quite new in the Jordanian market and due to the unavailability of the required data during the study period.

\subsection{Data Collection Methods}

Required data was collected from the annual reports, financial statements, sustainability reports - if any, and social responsibility reports of the Jordanian Islamic banking from (2008-2014). Items for the dimensions of sustainability was determined by G4 to measure the dimensions of sustainability, which consisted of the economic dimension (9 items) and environmental dimension (34 items) and the social dimension (49 items), and their level of exercise was measured by analyzing the content of these reports (content analysis), as well as the financial indicators of financial performance (return on assets, return on equity, and earnings per share), which have been extracted from the financial statements of the surveyed banks.

\subsection{Descriptive Analysis of the Variables}

\section{1). Indicators of Financial Performance}

Table 1. The statistical description of the financial performance indicators from (2008-2014)

\begin{tabular}{llcccc}
\hline Indicator & Bank & Mean & St. dev & Max & Min \\
\hline Return of assets (ROA) & Islamic Bank & 1.302 & 0.293 & 1.901 & 0.977 \\
& Islamic Arab Bank & 0.814 & 0.296 & 1.171 & 0.249 \\
Return on equity (ROE) & Islamic Bank & 16.557 & 2.610 & 21.828 & 13.691 \\
& Islamic Arab Bank & 1.367 & 0.501 & 1.911 & 0.413 \\
Earnings per share (EPS) & Islamic Bank & 0.320 & 0.057 & 0.433 & 0.279 \\
& Islamic Arab Bank & 0.102 & 0.043 & 0.157 & 0.026 \\
\hline
\end{tabular}

Table 1 refers to the difference in financial performance indicators between Jordan Islamic Bank and Islamic Arab Bank. The table expresses an increase in performance indicators for Jordan Islamic Bank, where the average (ROA) for the period was (1.302), compared with Arab Islamic Bank, which was (0.814). The average values of (ROE) during the period in Jordan Islamic Bank was (16.557), as compared with Arab Islamic Bank, which was (1.367). The average values of (EPS) in Jordan Islamic Bank during the period was (0.320), 
compared with Arab Islamic Bank, which was (0.102). Standard Deviation values have shown similarities in terms of stability. This confirms that all of the banks maintain their level of profitability. It also confirms the supremacy of the Islamic Bank in achieving returns, which may be due to the fact that Jordan Islamic Bank has been part of the market for a longer time and managed to grow its market share as the first Islamic bank in Jordan.

\section{2). Disclosure of the Dimensions of Sustainability}

Table 2. The statistical description of the level of practice of sustainability dimensions during the period (2008-2014)

\begin{tabular}{llcccc}
\hline \% & Bank & Mean & St. dev & Max & Min \\
\hline Economic dimension & Islamic Bank & 81.55 & 16.80 & 91.48 & 60.57 \\
& Islamic Arab Bank & 90.03 & 14.11 & 98.77 & 80.77 \\
Environmental dimension & Islamic Bank & 34.61 & 30.18 & 64.23 & 10.87 \\
& Islamic Arab Bank & 87.74 & 7.39 & 91.76 & 79.50 \\
Social dimension & Islamic Bank & 73.72 & 18.42 & 85.40 & 59.51 \\
& Islamic Arab Bank & 77.24 & 15.59 & 93.92 & 62.74 \\
Total & Islamic Bank & 66.27 & 20.77 & 81.62 & 49.02 \\
& Islamic Arab Bank & 81.34 & 13.59 & 94.13 & 68.94 \\
\hline
\end{tabular}

Table 2 indicates a considerable variation in the level of practice of sustainability dimensions between Jordan Islamic Bank and Arab Islamic Bank. The ratio of Arab Islamic Bank was higher for all dimensions which amounted to (81.34) (economic dimension: 90.03, Environmental Dimension: 87.74, social dimension: 77.24), while the ratio among Islamic Bank (66.27) (economic dimension: 81.55, environmental dimension: 34.61, social dimension: 73.72), and this may be due to the fact that Arab Islamic Bank follows Arab Bank, which is issuing annual sustainability reports periodically since 2010. This also refers to how much attention Arab Islamic Bank gives to sustainability practices from the economic, environmental, and social aspects.

\subsection{Testing the Hypotheses}

The data of the study's variables are cross-sectional time series data. Multiple regression analysis is the most appropriate model to measure the relationship between variables. This part of the study tests the hypotheses after confirming the suitability of the data for the study model and the description of the study's variables.

Table 3 shows the results of testing the hypotheses where the effect of practicing the dimensions of sustainability (economic dimension, environmental dimension, and social dimension) on the financial performance in Jordanian Islamic banks was tested. The results of the tests were presented as follows:

Table 3. Results of testing the hypotheses of the study

\begin{tabular}{|c|c|c|c|c|}
\hline Independent variables & $\begin{array}{c}\text { First hypothesis H01 } \\
\text { Dependant variable } \\
\text { EPS } \\
\end{array}$ & $\begin{array}{c}\text { Second hypothesis } \mathrm{H02} \\
\text { Dependant variable } \\
\text { ROE }\end{array}$ & $\begin{array}{c}\text { Third hypothesis } \mathrm{H03} \\
\text { Dependant variable } \\
\text { ROA }\end{array}$ & VIF \\
\hline Economic dimension & $\begin{array}{c}0.541 \\
(12.725)^{* *}\end{array}$ & $\begin{array}{c}3.494 \\
(4.089)^{* *}\end{array}$ & $\begin{array}{c}1.122 \\
(3.180)^{* *}\end{array}$ & 2.323 \\
\hline Environmental dimension & $\begin{array}{c}0.222 \\
(3.721)^{* *}\end{array}$ & $\begin{array}{l}-0.217 \\
(-0.822)\end{array}$ & $\begin{array}{c}0.178 \\
(0.637)\end{array}$ & 1.714 \\
\hline Social dimension & $\begin{array}{c}0.764 \\
(6.679)^{* *}\end{array}$ & $\begin{array}{l}-1.780 \\
(-1.173)\end{array}$ & $\begin{array}{c}0.404 \\
(2.117)^{*}\end{array}$ & 2.958 \\
\hline $\begin{array}{c}\text { Determination factor }\left(\mathrm{R}^{2}\right) \\
\text { Calculated value of } F\end{array}$ & $\begin{array}{c}0.326 \\
(6.812)^{* *}\end{array}$ & $\begin{array}{c}0.083 \\
(0.906)\end{array}$ & $\begin{array}{c}0.195 \\
(2.993)^{*}\end{array}$ & \\
\hline $\mathrm{D}-\mathrm{W}$ & 1.878 & 1.793 & 1.811 & \\
\hline
\end{tabular}

* Significant at the level of significant 0.05 ;

** Significant at the level of significant 0.01 .

Note. The value in the first row refers to the value of the regression coefficient, while the second row, which is between the brackets, refers to the value of t. Note that the total views amounted to 252 views.

Depending on Table 3 above, we can conclude the following:

1). Testing the results of the first hypothesis: The results of Table 3 show that the effect of sustainability 
dimensions on ROA is a significant effect, as the value of $(\mathrm{F}=2.993)$ with the level of significance being less than 0.05 . The value of the determination coefficient $\left(R^{2}=0.195\right)$ indicated that the $19.5 \%$ of the variation in the ROA can be explained by the combined variables. The results also showed that the value of the regression coefficients, the impact (economic dimension), has a significant effect, where the value of the regression coefficient was (1.122), and the level of significance was less than 0.01. The impact of (environmental dimension) was non-significant, as the value of the regression coefficient was $(0.178)$, and the level of significance was more than 0.05 . The effect of (social dimension) was significant, as the value of the regression coefficient was (0.404), and the level of significance was less than 0.05. Accordingly, we reject the first hypothesis and accept the alternative, which states: "There is a statistically significant impact at the level of significance $(\alpha \leq 0.05)$ for the dimensions of sustainability on the financial performance measured by ROA in Jordanian Islamic banks".

2). Testing the results of the second hypothesis: The results of Table 3 show that the effect of sustainability dimensions on ROE is a non-significant effect, where the value of $(\mathrm{F}=0.906)$ with the level of significance being more than 0.05 . The value of the determination coefficient $\left(\mathrm{R}^{2}=0.083\right)$ indicated that the $8.3 \%$ of the variation in the ROE can be explained by the combined variables. The results also showed that the value of the regression coefficients, the impact (economic dimension), has a significant effect, where the value of the regression coefficient was (3.494), and the level of significance was less than 0.01. The impact of (environmental dimension) was non-significant, as the value of the regression coefficient was (- 0.217), and the level of significance was more than 0.05 . The effect of (social dimension) was non-significant, as the value of the regression coefficient was (-1.780), and the level of significance was more than 0.05 . Accordingly, we accept the second hypothesis, which states: "There isn't a statistically significant impact at the level of significance $(\alpha \leq 0.05)$ for the dimensions of sustainability on the financial performance measured by ROE in Jordanian Islamic banks".

3). Testing the results of the third hypothesis: The results of Table 3 show that the effect of sustainability dimensions on EPS is a significant effect, where the value of $(\mathrm{F}=6.812)$ with the level of significance being less than 0.05 . The value of the determination coefficient $\left(R^{2}=0.326\right)$ indicated that the $32.6 \%$ of the variation in the EPS can be explained by the combined variables. The results also showed that the value of the regression coefficients, the impact (economic dimension), has a significant effect, where the value of the regression coefficient was (0.541), and the level of significance was less than 0.01. The impact of (environmental dimension) was significant, as the value of the regression coefficient was (0.222), and the level of significance was more than 0.01 . The effect of (social dimension) was significant, as the value of the regression coefficient was (0.764), and the level of significance was less than 0.05 . Accordingly, we reject the third hypothesis and accept the alternative, which states: "There is a statistically significant impact at the level of significance $(\alpha \leq 0.05)$ for the dimensions of sustainability on the financial performance measured by EPS in Jordanian Islamic banks".

\section{Results and Recommendation}

The results of the statistical analysis showed that the financial performance indicators (EPS, ROE, ROA) in Jordan Islamic Bank during the period (2008-2014) were high compared to Arab Islamic Bank. This can be attributed to the primacy of Jordan Islamic Bank in the banking market, which allowed it to grow its market share. The results also showed that Islamic Arab Bank is ranked first in the practice of sustainability dimensions (economic dimension, environmental dimension, and social dimension) compared to Jordan Islamic Bank. This can be attributed to the fact that Islamic Arab Bank is affiliated to Arab Bank, which is one of the first Jordanian banks to pay great attention to sustainability and commit to issuing sustainability reports periodically.

With regard to the results of testing the hypotheses, the results have shown the presence of a statistically significant effect at the level of significance $(\alpha \leq 0.05)$ of the dimensions of sustainability on the financial performance measured by ROA and EPS in the Jordanian Islamic banks. However, there was no statistically significant effect at the level of significance $(\alpha \leq 0.05)$ of the dimensions of sustainability on the financial performance as measured by ROE in those banks. These results agreed there was a significant economic impact on financial performance as measured by return on assets, return on equity, and earnings per share in Islamic banks, while results were dissimilar on the impact of environmental and social dimension of the financial performance of those banks, which may be due to the fact that the community and private investors focus on economic activities of the bank and its ability to achieve financial objectives and maximize their wealth than any other activity carried out by the bank.

Based on the findings of the study, the author recommends that Islamic banks adopt a rational and prudent 
investment and financial policies and make proper operational decisions, in an effort to achieve its objectives to generate revenue, maximize profits, and achieve shareholder objectives. The author encourages Islamic bank to issue sustainability reports to reveal that their goals and activities are compatible to the goals and interests of society and the environment, and promote these banks to increase their interest in sustainability.

The study also encourages Islamic banks to improve their financial performance and adopt suitable methods and policies to achieve this goal. This objective can be accomplished by applying the disclosure of sustainability dimensions on a regular basis, increasing the capacity and skills of accountants - teach them how to prepare sustainability reports, and making concerned individuals more aware of the importance of the implications. Finally, the study recommends the conduction of more researches and studies in the future and the adoption of other financial performance indicators.

\section{References}

Albu, N., Nicolae, C., Madalina, M., \& Iuliana, M. (2011). The Implications of Corporate Social Responsibility on the Accounting Profession: The Case of Romania. Amfiteatru Economic, 29, 221-234.

Bansal, T., \& Ivey, R. (2013). The Financial Times Ltd. School of Business, University of Western Ontario.

Dufera, A. (2010). Financial Performance Evaluation: A Case Study of Awash International Bank (AIB). Master Thesis, Mekelle University.

Egos, J. G. (2005). Evaluation of Accounting Information to Anticipate the Financial Value. Financial Magazine, (156).

Gibson, C. H. (2013). Financial Reporting \& Analysis: Using Financial Accounting Information (13th ed.). College Book Store, Inc.

Godard, O. (2010). The Economic Enterprise for Sustainable Development: Challenges and Environmental Policies. French Notebooks, No. (306), France.

Gonzalez, C. L., \& Adam, A. A. (2012). Engaging with Organizations in Pursuit of Improved Sustainability Accounting and Performance. Accounting Auditing \& Accountability Journal, 20(3), 333-355.

Guidry, R. P., \& Patten, D. M. (2010). Market Reactions to the First - Time Issuance of Corporate Sustainability Reports: Evidence that Quality Matters. Sustainability Accounting, Management and Policy Journal, l(1), 33-50. https://doi.org/10.1108/20408021011059214

Inoue, Y., \& Lee, S. (2011). Effects of Different Dimensions of Corporate Social Responsibility on Corporate Financial Performance in Tourism - Related Industries. Tourism Management, 32(4), 790-804. https://doi.org/10.1016/j.tourman.2010.06.019

International Federation of Accountants (IFAC). (2006). Why Sustainability Counts for Professional Accountants in Business. Retrieved from http://www.ifac.org

Iucn/unep/wwf. (1991). Caring for the Earth: A Strategy for Sustainable Living. Gland, Switzerland.

Macarulla, F., \& Talalweh, M. (2012). Voluntary Corporate Social Responsibility Disclosure: A case Study of Saudi Arabia. Journal of Business Administration, 8(4), 815-830.

Organization for Economic Co-Operation and Development (OECD). (2002). Principles of Corporate Government (pp. 59-66). Retrieved from http://www.Oecd.Org

Poster, T. H., \& Streib, G. (2005). Elements of Strategic Planning and Management in Municipal Government: Status After Two Decades. Public Administration Review, 65(1). https://doi.org/10.1111/j.1540-6210.2005.00429.x

Rankin, M., Stanton, P., McGowan, S., Ferlauto, K., \& Tilling, M. (2012). Contemporary Issues in Accounting (1st ed.). New York: Wiley \& Sons.

Reid, W., \& Myddelton, D. R. (2005). The Meaning of Company Accounts (8th ed.). Gower Pub Co.

Schallegger, S., \& Wagner, M. (2006). Integrative Management of Sustainability Performance, Measurement and Reporting. International Journal of Accounting, Auditing and Performance Evaluation, 3(1), 1-19. https://doi.org/10.1504/IJAAPE.2006.010098

Sinkey, J. (2008). Commercial Bank Financial Management (5th ed.). Newjersy.

Smouts, M. C. (2005). Sustainable Development. Editions Armand Colin, France.

Thomas, L., \& Vos, C. (2012). Sustainability Reporting with an Environmental Focus: A Comparative Analysis 
from the Logistics Industry. Lund University School of Economics and Management, Sweden.

United Nations General Assembly. (2005). World Summit Outcome, Resolution A/60/1. Adopted by the General Assembly on 15 September 2005.

Weygandt, J. J., Kieso, D. E., \& Kimmel, P. D. (2010). Intermediate Accounting IFRS Edition (1st ed.). John Wiley \& Sons, Inc.

Zvedov, D. (2012). Stages of Engaging with Corporate Sustainability Accounting. Journal of the Asia-Pacific Centre for Environmental Accountability.

\section{Copyrights}

Copyright for this article is retained by the author(s), with first publication rights granted to the journal.

This is an open-access article distributed under the terms and conditions of the Creative Commons Attribution license (http://creativecommons.org/licenses/by/4.0/). 